\title{
SMALL BUSINESSES IS A SPHERE OF INNOVATION IN THE AGE OF GLOBALIZATION
}

\author{
Dr Liudmila Gennadyevna Romanovich* \\ Belgorod State Technological University named after V.G. Shukhov, Russia \\ Marina Alexeevna Romanovich \\ Belgorod State Technological University named after V.G. Shukhov, Russia \\ Dr Valentina Vladimirovna Vybornova \\ Belgorod State Technological University named after V.G. Shukhov, Russia \\ Dr Riapukhina Viktoriia Nikolayevna \\ Belgorod State Technological University named after V.G. Shukhov, Russia
}

The achievement of a sustainable growth and competitive of national growth is a cross-cutting theme, the success of it is determined the development of economic institutes and establishing of new competitive position. The maximum competitive becomes an economic in which knowledge and innovation are created, distributed and used effectively. Therefore, at the present stage of development of the world economic system transition to a knowledge economy is becoming one of the key elements of a national strategy to improve the country's competitiveness in the international arena. The article considers actual questions of small innovation business development in modern terms - increase the global competition for the factors which determine the competitiveness of innovative systems, primarily for highly skilled labor force and the "smart» money (investments, which attracting projects in new knowledge, technologies, and competencies), a sharp increase in the mobility of these factors.

Key words: Small innovative enterprises, Globalization, Innovation, Technology transfer

\section{INTRODUCTION}

In economically developed countries, the small business sector make a conspicuous figure in the socio-economic development and raising of welfare standards of the population, provides a significant share of gross domestic product and employment. In advanced foreign countries a small business innovation has become a major investment target. Consuming from 2 to $5 \%$ of the total funding in science and technology, small high-tech businesses create $50 \%$ of major innovations and be licensors are almost $50 \%$ of innovation in the global market. In most developing industries (computer science, electronics and biomedical engineering) from the total number of firms operating small businesses with up to 100 people make up more than $80 \%$ [08].

The world socio-economic situation is characterized by: a high rate of technological development and modernization, globalization of production and markets, increased requirements to the quality of goods and services, the introduction of uniform international standards of quality. But small businesses for the most part not in a posi- tion to realize the plenitude of the management functions. This applies to resource support at the start of the business and minimizing the cost of service management functions, such as market research, partner search and orders, information and legal support, etc. Therefore, small businesses need the support of the state and public institutions [10,07].

Subject to support small businesses in the context of globalization has gained special relevance in the post-Soviet states owing to the underdevelopment of mechanisms and problems with the improvement of the business climate. Thus, the results of nationwide poll conducted in June 2013 the All-Russian Public Opinion Research Center (ACSPO) are showed that over the past four years, the Russians have become more negatively evaluate conditions for the development of business in their community (Table 1).

For example, if in 2009 the adverse conditions for development of small businesses felt $44 \%$, today - already $55 \%$. The view a proposal of the situation, to begin with, primarily residents of small towns and villages (62\%) and 35-44-year- 
olds (63\%). A quarter of respondents believe that the conditions for private sector development in their place of residence - good (25\%). Basically it is the city residents multi-million-strong cities (36\%), large cities (34\%) and 18-24-year-old Russians (31\%). Most Russians do not have your own business, have reported they have no plans in the future to acquire their own business $(72 \%)$ - in 2011 the figure was $65 \%$. About $16 \%$ people are planning to be an entrepreneur $16 \%$ (two years ago - 20\%) - mostly 18-24-year-olds $(38 \%)$ and residents of over a million (24\%). In the past, $7 \%$ were trying to do business, but was unsuccessful [04].

Table 1: The results of public-opinion poll [07]

\begin{tabular}{|l|c|c|}
\hline \multicolumn{2}{|c|}{$\begin{array}{c}\text { What do you think what in our city (village) conditions for the development of small business, } \\
\text { private enterprise? (close-ended question, one answer) }\end{array}$} \\
\hline Response & 2009 year & 2013 year \\
\hline Conditions, certainly, good & 3 & 2 \\
\hline Rather good & 27 & 23 \\
\hline Rather bad & 31 & 38 \\
\hline Conditions, certainly, bad & 13 & 17 \\
\hline Difficult to answer & 26 & 20 \\
\hline
\end{tabular}

The above trend in small business, and especially in the innovation (share does not exceed $2 \%$ in the overall structure of small business), there is the context of global changes in the world economy. At the modern stages of development they economics are facing long-term systemic challenges that reflect global trends and internal obstacles to development: increased global competition, embracing not only the traditional markets for goods, capital, technology and labor, but also a system of national governance, support innovation, human development and others.

Also further ought to mention is the high competition and market volatility innovation. In confirmation of this is the example of how a new list of the most innovative companies known corporation Apple ranked $79^{\text {th }}$, although in 2011 . It was on the 5th position in 2012 - on the 26th line. At this rate, this year the company lost 53 positions immediately in the list of innovative companies according to Forbes [04].

Global Innovation Index (The Global Innovation Index) - a global studies and the accompanying ranks countries in terms of development of innovations according to the international business school INSEAD. In 2013, the study covers 142 countries, which once again confirms the high level of competition and volatility in the country's leadership in innovation [05].

The top ten countries - leaders in 2013:

1. Switzerland (1 in 2012)

2. Sweden (2)

3. Kingdom
4. Netherlands (6)

5. United States of America(10)

6. Finland (4)

7. Hong Kong (China) (8)

8. Singapore (3)

9. Denmark (7)

10. Ireland (9).

Analyzing the above list of countries clearly shows the definition of a place in the top ten leading countries and changes in 2013 compared to 2012. It is fair to assume that analyzing innovation by these countries can see the overall trends, the course of innovation activity. Diagram of interest "Investing in innovation relative to GDP" (Figure 1 ). This diagram is compiled from public sources and Internet resources relevant to 2011 [03].

It is evident, the activities have changed in 2013 , but the indicated proportion of it tell about the huge reserves in the development of innovation, given the significant changes in fiscal policy to support the innovation movement in the Russian Federation. In this context, suitable statement that "... the one who leads the pack in innovation development, and he is the leader ..." [02].

At this rate, it is natural that in the Concept of long-term socio-economic development of the Russian Federation for the period up to 2020 indicates that the Russian economy is facing long-term systemic challenges that reflect global trends and internal obstacles to development. Key among these external calls on innovative development are: acceleration of technological 
development in the world economy. The real competitors of Russian are not only the leading countries in terms of innovation, but also many developing countries. The transition economies of the leaders of the next (sixth) technological system, the technological revolution in resource saving and alternative energy, dramatically increases the uncertainty in the development of the country, which is the basis of expertise in the global markets of export of conventional energy sources.

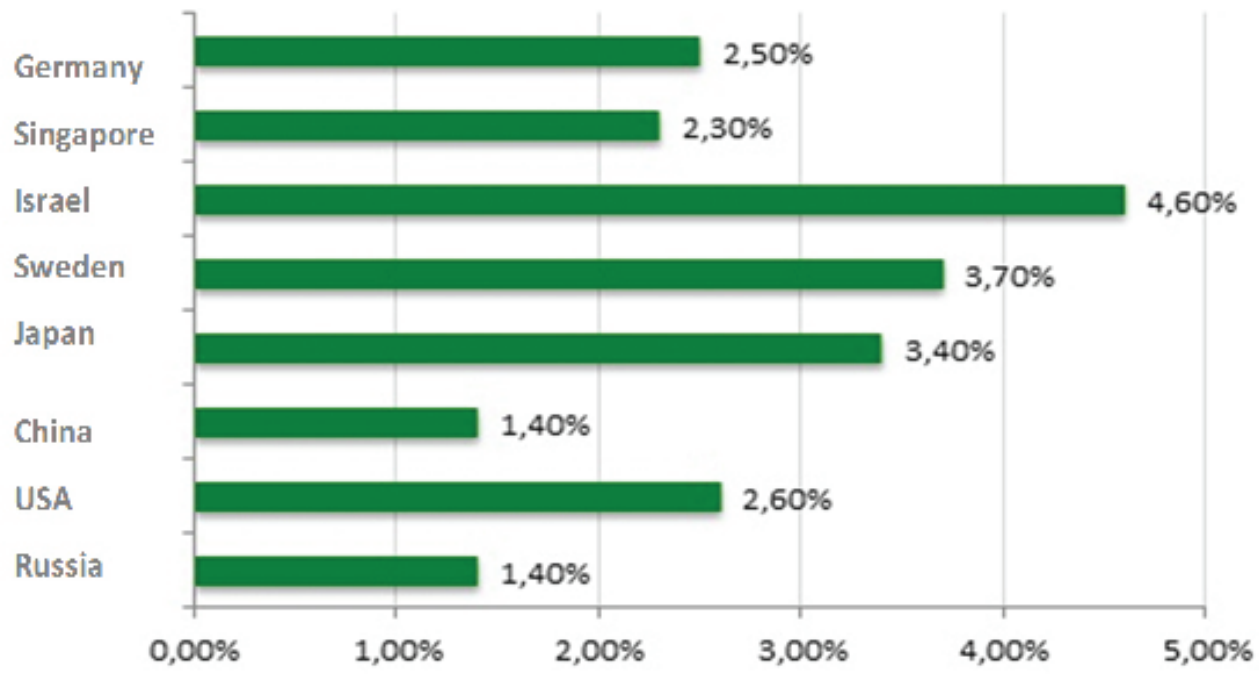

Figure 1: Investment in innovation in relation to GDP

Crisis in 2009 is heightening the importance of this invitation for Russia. This is due primarily to the fact that investment in technological development, "an innovative breakthrough" is considered developed countries (USA, Japan, the "old" EU member states), and the growing economies of China, India and Brazil as a key anti-crisis measures.

Investments that are supposed to be implemented for several years, were sharply "approximate" - within the frame of package of anti-crisis developed countries allocated tens of billions of dollars in additional investment in the development of medicine, biotechnology, alternative and renewable energy, nuclear industry and information technology. So powerful financial injections for 35 years can bring change technological order.

One of the key challenges for the country it is increased global competition for factors determining the competitiveness of innovative systems, primarily for highly-qualified labor power and the 'smart' money (investments, projects attracting new knowledge, technology, competence), a sharp increasing the mobility of these factors. Under conditions of low efficiency of the national innovation system, this means rapid "washout" of the country to remain competitive capacity training, technology, ideas, and capital.

Challenges faced not only Russian, but also humanity as a whole - climate change, an aging population and the challenges of health, food security globally. These challenges dictate the need for advanced development of individual specific areas of scientific research and technological development ("clean" energy, genomic medicine, new technologies in agriculture, etc.), many of which, in many countries there is no significant backlogs.

For the purpose of to answer on these challenges, Russia must radically more deeply to integrate into the global innovation system. Same inequality to answer on these challenges means narrowing the "windows of opportunity" for the transition to an innovation economy, the continuing loss of scientific potential weakening geopolitical position, the transition to the category of countries with innovative simulation type not capable of producing new knowledge and to achieve global leadership in key technology areas, long-term consolidation of the raw nature of the economy, low rates of economic growth. This is means that you cannot achieve the goals and objectives of the long-term development [06].

At the same time in the concept of long-term socio-economic development of the Russian Federation for the period up to 2020 identified ambitious goals - ensuring a high level of welfare, strengthening the country's geopolitical role as one of the global leaders in defining the global political agenda. This means the need to build 
the economy of leadership and innovation. Quantitative indicators of an economy by 2020 - a substantial share of employment (5-10 per cent) in the markets of high-tech and intelligent services for 5-7 items, increased by half the proportion of high-tech sector in GDP (from 10.9 to $17-20 \%)$, an increase of five to six times the share of innovative products in the production industry, four or five times - the share of innovation active enterprises (from 9.4 to $40-50$ percent).

\section{CONCLUSION}

In our opinion, and according to some analysts, in Russia and other post-Soviet states transition to an innovative model delayed. Small business and especially in the field of innovation, yet does not have the substantial state support and benefits to help provide a "breakthrough innovation" and the socio-economic growth in countries such as USA, Japan, the "old" EU Member States [10].

Currently in the field of individual technologies occurs gap with the developed countries for several decades. Over twenty years of reforms implemented and utilized about $10 \%$ of significant innovations in production.

\section{SUMMARY}

At this rate, analyzing the problems of the modern development of small innovative businesses in the context of globalization, consider it appropriate to turn attention to the following aspects:

1) According to our reckoning, the difficult economic situation on a short-term horizon is not talking about the need to revise long-term development, rather the need to "increase the bar" for the rate of socio-economic development and to take immediate and effective measures cardinal small business development, especially in sphere of innovation.

2) As to the positive experience has proven that economically developed countries - in the innovation economy is the state assumes the leadership role which could accumulate and disseminate knowledge on industrial strategy to be pursued at all levels, and caused her transformations, actively participates in the development and promotion of innovative advantages territory.

3) The world practice a combination of measures and forms of innovation of small businesses is diverse and extensive. In the recent decade there is obtaining a positive experience in Russia and Moldova. At the same time, the development of innovative processes in postSoviet states is slow, not always done the right choice of priorities and instruments of innovation that contributes to the crisis in science and technology, leading to a misallocation of significant financial resources.

4) It is new technology and provides efficiency gains allow them to achieve the main conditions of the national (country) and industrial competitiveness: the production of goods and services that meet the requirements of global markets, on the basis of high productivity and while increasing real incomes.

5) It is necessary and possible to build an innovative economy based on international experience with international partners, using approaches that are in the most advanced countries with respect to those or other technological and institutional solutions. For example, the American experience of venture capital financing, it is can significantly promote the innovation process in the country. [01, 11, 09]

6) Increase funding and changes in institutional and structural features of the development.

7) Increase the proportion of organizations that are engaged in research and development in their total number of innovative products in total production, and Russian patents for inventions;

8) A great interest in the development of innovation shows a small business and there is a need to support it. In the meantime, the main direction of innovation in business - extensive: technological innovation (primarily the acquisition of machinery and equipment ready abroad), whereas organizational and marketing have little development.

\section{ACKNOWLEDGEMENTS}

The authors extend acknowledgements to the rector of BSTU, prof. Sergei Nikolaevich Glagolev for their assistance in organizing the study and publication of the results. Work has been performed in the framework of Strategic Development Program at BSTU for 2012-2016. The article was published with the financial support from Ministry of Education and Science of the Russian Federation within the framework of state assignment to the project \#26.1511.2014K "Theory and methodology of managing innovational and investment processes in small business enterprises." 


\section{REFERENCES}

1) Concept of long-term socio-economic development of the Russian Federation until 2020. approved by the Federal Government on November 17, 2008 № 1662-p. - System GARANT (CD-ROM).

2) http://concol.ru/en/analytics/we-are-inpress/28-vpirit/188-a-brief-overview-of-thedevelopment-of-innovations-in-russia-andworldwide (date accessed 08/24/2013).

3) http://gtmarket.ru/ratings/global-innovationindex/info (date accessed 24/08/2013).

4) http://wciom.ru/index.php?id=459\&uid $=114167$ (date accessed 08/24/2013). Official website for the All-Russian Public Opinion Research Center (ACSPO)

5) http://www.vestifinance.ru/articles/31202 (date accessed 24/08/2013).

6) Meadow E., 2012. Innovation as a basis for the modernization of modern society. Bulletin of Volgograd State University, 7 (2): 17

7) Romanovich A., V. Bogdanov and N. Vorobyov, 2013. Definition of rational conditions of materials griding in energy-saving milling complex. World Applied Sciences Journal, 25 (2): 214-221.

8) Romanovich, L., Rudichev, A., Romanovich, M., Lycheva, A. (2013). Incentives for Innovative Activity of Young Scientists on the Basis of Higher Educational Institutions in Russia. Experience of Belgorod State Technological University named after V.G. Shukhov. World Applied Sciences Journal, No. 25 (12), pp. 1754-1757.

9) Romanovich M.A, A. Rudichev and L. Romanovich, 2011. Venture investment in innovative enterprises abroad and in Russia. Bulletin of Belgorod State Technological University named after V.G. Shukhov, (4): 123-126.

10) Romanovich, L., Roscovanu, E., Vinokurova, M. (2010) International experience of innovation in the small business. Monograph. Belgorod, BSTU named after V.G. Shukhov, pp. 150

11) Vybornova V.V, 2009. Factors determining the production capacity of Belgorod. Economic Bulletin, 2 (54): 68-70.

Paper sent to revision: 23.10.2014.

Paper ready for publication: 15.12.2014. 